\title{
First record of Enoplometopus callistus (Crustacea: Decapoda: Nephropidae) in the Cape Verde Islands
}

\author{
Sonia Elsy Merino ${ }^{\ddagger}$ and J. Alistair Lindley ${ }^{\dagger}$ \\ *Instituto Nacional de Desenvolvimento das Pescas (INDP), CP 132, Mindelo, S. Vicente, Cabo Verde, West Africa. \\ ${ }^{\dagger}$ Sir Alister Hardy Foundation for Ocean Science, The Laboratory, Citadel Hill, Plymouth, PL1 2PB. \\ ${ }^{\ddagger}$ Corresponding author, e-mail: soniaelsy@yahoo.com
}

\begin{abstract}
Enoplometopus callistus is reported for the first time from the Cape Verde Islands. In January 2001 two specimens were captured in depths of 100-150 $\mathrm{m}$ as by-catch in the lobster fisheries. One of them was dissected and kept in alcohol for future reference, the second one was put into an aquarium. The existing data on the distributions of the two Atlantic species of this genus, E. antillensis and E. callistus, indicate that the latter is restricted to the waters of the East Atlantic.
\end{abstract}

In the Atlantic Ocean González Pérez (1995) reported two species of the genus Enoplometopus: E. callistus Intés \& Le Loeuff, 1970 and E. antillensis Lutken, 1865. The nomenclature and classification of this genus and of some of the species it includes has been controversial, probably related to similar morphologies among species together with the rarity with which these species are captured. De Saint Laurent (1988) placed this genus in its own family, Enoplometopidae, in the infra-order Astacidae, although González Pérez (1995) includes it with the Axiidae, Huxley, 1879.

In the West Atlantic E. antillensis has been cited from the north of Brazil to Florida and in the Bahamas and Bermuda archipelagos. The first records from the East Atlantic were by Wirtz et al., 1988 from the Canary and the Cape Verde archipelagos, further records from Madeira, Ascencion São Tomé, St Helena and Gabón were added by González Perez, 1995, Wirtz \& Herrera, 1995 and Poupin, 2002.

Enoplematopus callistus is known from some islands in the Canary Archipelago (González Pérez, 1995), Nigeria (Burokobsky, 1972 as E. biafri) and Ghana (Intés \& Le Loeuff, 1970). In the Canary Islands, Wirtz \& Herrera (1995) describe it as occurring typically in the depth range $5-30 \mathrm{~m}$, and they also reported its casual capture by the fishermen between 40 and $200 \mathrm{~m}$.

In January 2001, the National Institute for Fisheries Development (INDP) received two examples of the crustacean species Enoplometopus callistus from fishermen working in the deep-water lobster fisheries (Palinurus charlestoni Forest \& Postel, 1964). The specimens were captured as by-catch with traps, between depths of 100-150 m. One was taken from hauls, to the north of São Nicolau, the second one from hauls made to the north of Santo Antão (islands in the Barlovento region). The fishermen also reported having captured another example to the north of Brava (island in the Sotavento region). One specimen was preserved in alcohol, and the other was kept in an aquarium $\left(21-25^{\circ} \mathrm{C}\right)$ for seven months.

Available data indicate that E. callistus is a rare species in the Cape Verde archipelago with a distribution restricted to deep rocky grounds. The absence of the species in the coastal zone might be related to the sharp drop of the insular shelf that characterizes the major part of the islands and, perhaps related to this, the lack of the appropriate food.
The identification of the specimens as E. callistus is based on the description given by Intés \& Le Loeuff (1970). The four median and two lateral spines on the carapace (Figure 1) are diagnostic of the species. There were two well separated anterior spines of the telson, and there was no white circle around a white spot on both sides of the carapace (Figure 1), mentioned by Wirtz \& Herrera, 1995, as characteristic of E. antillensis.

Since the initial report of Wirtz et al. (1988) of E. antillensis in the Cape Verde Islands, there have been no further records from the archipelago. The present records establish that the two species occur in the Cape Verde Islands, although they are rare.

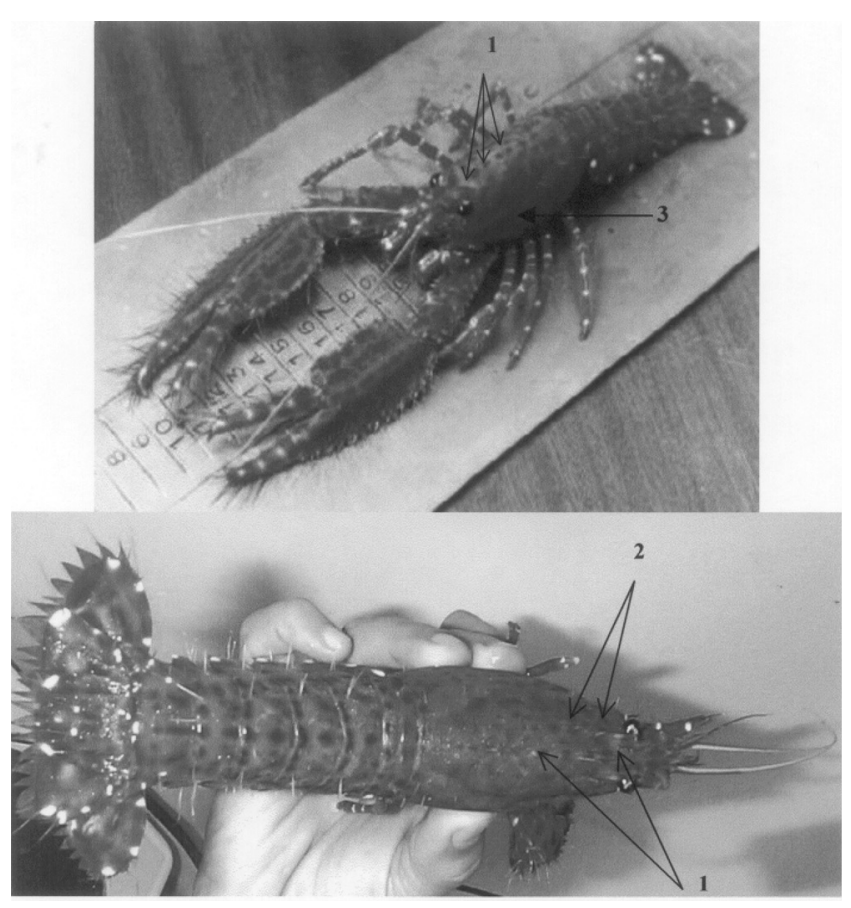

Figure 1. Enoplometopus callistus showing some of the distinctive characteristics for this species: (1) four median carapace spines; (2) two lateral carapace spines; and (3) absence of the white circle around a white spot on both sides of the carapace. 
We acknowledge advice from Dr Nancy Knowlton, Dr Fatima Hernandez and Dr Emilio Roland. We would also like to specially thank Nelson Atanacio's (the ship's owner) crew for supplying the specimens.

\section{REFERENCES}

De Saint Laurent, M., 1988. Enoplometopidae, nouvelle superfamille de Crustacés Décapodes Astacidae. Comptes Rendus Hebdomedaire des Séances de l'Académie des Sciences, Paris. Zoologie, 307, 59-62.

González Pérez, J.A., 1995. Catálogo de los Crustáceos Decápodos de las Islas Canarias. Santa Cruz de Tenerife: Publicaciones Turquesa.

Intés, A. \& Le Loeuff, P., 1970. Sur une nouvelle espéce du genre Enoplometopus A. Milne Edwards du golfe de Guinée: Enoplometopus callistus nov. sp. Bulletin du Muséum d'Histoire Naturel, Série 2, 41, 1442-1447.
Poupin, J., 2002 onwards. Tropical reef lobsters of the genus Enoplometopus (Astacidea, Enoplometopidae): descriptions, illustrations, identification, and information retrieval. http://biomar.free.fr/ enoplometopus/

Wirtz, P. \& Herrera, R., 1995. The lobster Enoplometopus antillensis (Decapoda: Enoplometopidae), and the goby Gobius xanthocephalus (Pisces: Gobiidae) - new records for the marine fauna of the Canary Islands. Arquipélago, Life and Marine Science, 13A, 115-118.

Wirtz, P., Muller, P. \& Nahke, P., 1988. The Caribbean shrimp Tuleariocaris neglecta Chace, 1969 found in association with Diadema antillarum at Madeira and two new records of decapod crustaceans from the Cape Verde Islands. Courier Forschungs Institut Senckenberg, 105, 167-171.

Submitted 26 January 2003. Accepted 6 September 2003. 